Environnement Urbain

Urban Environment

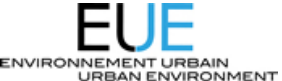

\title{
Radical Green Political Theory and Land Use Decision Making for Sustainability in the Region of Waterloo, Ontario, Canada
}

\section{Tanya Markvart}

Volume 3, 2009

Urbanisme et développement durable

Urban Planning and Sustainable Development

URI : https://id.erudit.org/iderudit/037601ar

DOI : https://doi.org/10.7202/037601ar

Aller au sommaire du numéro

Éditeur(s)

Réseau Villes Régions Monde

ISSN

1916-4645 (numérique)

Découvrir la revue

Citer cet article

Markvart, T. (2009). Radical Green Political Theory and Land Use Decision Making for Sustainability in the Region of Waterloo, Ontario, Canada.

Environnement Urbain / Urban Environment, 3, 64-82.

https://doi.org/10.7202/037601ar

\section{Résumé de l'article}

La théorie de la politique verte et radicale propose certains des fondements de la société durable. Le si et le comment on devrait joindre le geste à la parole sont aujourd'hui des questions de débat. Cette étude examine le rôle potentie de la théorie de la politique verte et radicale dans les processus de décisions en vue d'établir un aménagement du territoire favorable au développement durable. Les critères qui s'inscrivent dans le cadre des processus de décision liés à l'aménagement du territoire sont tirés des travaux de Dobson (2000) sur l'écologisme. Ils sont évalués, par la suite, en fonction des critères de base de la prise de décision en faveur de la durabilité définis par Gibson et al. (2005). Les points forts et les limites de l'ensemble des critères revus sont examinés à la lumière du cas d'aménagement de la Moraine Waterloo à Waterloo, Ontario, Canada. 


\title{
RADICAL GREEN POLITICAL THEORY AND LAND USE DECISION MAKING FOR SUSTAINABILITY IN THE REGION OF WATERLOO, ONTARIO, CANADA
}

\author{
Tanya MARKVART
}

\begin{abstract}
I RÉSUMÉ
La théorie de la politique verte et radicale propose certains des fondements de la société durable. Le si et le comment on devrait joindre le geste à la parole sont aujourd'hui des questions de débat. Cette étude examine le rôle potentiel de la théorie de la politique verte et radicale dans les processus de décisions en vue d'établir un aménagement du territoire favorable au développement durable. Les critères qui s'inscrivent dans le cadre des processus de décision liés à l'aménagement du territoire sont tirés des travaux de Dobson (2000) sur l'écologisme. Ils sont évalués, par la suite, en fonction des critères de base de la prise de décision en faveur de la durabilité définis par Gibson et al. (2005). Les points forts et les limites de l'ensemble des critères revus sont examinés à la lumière du cas d'aménagement de la Moraine Waterloo à Waterloo, Ontario, Canada.

MOTS-CLES - Écologisme, évaluation environnementale, politique environnementale, écologie politique, développement durable, planification urbaine
\end{abstract}

\begin{abstract}
- ABSTRACT
Radical green political theory outlines some fundamentals for a sustainable society; if and how they might be translated into practice has become a matter of much discussion. This study investigates the role that radical green political theory might play in land use decision making for sustainability. Land use decision making criteria are derived from Dobson's (2000) portrayal of ecologism and evaluated against Gibson et al.'s (2005) core decision making criteria for sustainability. Strengths and limitations of a revised set of criteria are investigated by applying them to the particulars of the Waterloo Moraine land use case in Waterloo, Ontario, Canada.
\end{abstract}

KEYWORDS - Ecologism, environmental assessment, environmental politics, political ecology, sustainable development, urban planning 


\section{INTRODUCTION}

Radical green political theory outlines some fundamentals for a sustainable society; if and how they might be translated into practice has become a matter of much discussion. To be effective for complex socioecological problem-solving, radical green political theory must adapt to a diverse range of local to global contexts. This study investigates the role that radical green political theory might play in land use decision-making for sustainability. It aims to begin to delineate the components of radical green political theory on which green political theorists might focus in order to strengthen capacity to achieve sustainability in the context of real life socio-ecological problem solving.

For this purpose, a critical review was undertaken of Dobson's (2000) portrayal of ecologism, the political ideology underpinning radical green political theory. A set of preliminary, generic land use decision making criteria was developed based on Dobson's portrayal of ecologism. Dobson's depiction was selected over other interpretations (e.g., Smith, 1998) because the group of green political theorists referred to by this study most often cite Dobson's work. Moreover, Dobson's account of ecologism has received wide commentary from notable political theorists. Goodin's (1992) reflections on the "green theory of value" and the "green theory of agency", for example, are inclusive of Dobson's (1990) description of the radical green agenda. Dobson's most recent editions of Green Political Thought $(2000,2006)$ are, in part, a response to the explosion of literature on green political theory since the first edition was published in 1990. Dobson's work therefore reflects the growth most recently experienced by the political ideology of ecologism.

The capacity of the preliminary, generic land use decision making criteria to achieve sustainable development was then tested against Gibson et al.'s (2005) core decision making criteria for sustainability (Test I). Gibson et al. recognize the vastness of the literature on the concept of sustainability and the many ways that the concept has been interpreted and practiced throughout the world (see Chapter 3 " Sustainablity: The Essentials of the Concept", p. 38 - 65). The essentials that Gibson et al. chose for their conception of sustainability are (a) based on their synthesis of the theoretical literature (since the 1970s) on sustainability; (b) underpinned by their intention to delineate "those that lie at the core of the idea and that should inform its application anywhere" (p. 59); and (c) a reaction to the challenges previously (within the last twenty years) and currently faced by the practice of environmental assessment. In the context of these challenges, Gibson et al. attempt to clarify the concept of sustainability and then push it further into decision making. Box I below depicts Gibson et al.'s essentials of the concept of sustainability.

These criteria integrate considerations and insights from a range of disciplines, fields, and recent sustainability implementation efforts (corporate greening, ecological economics, ecological systems theory, growth management planning, etc.). Gibson et al. (2005) developed these criteria in order to unify the practice of environmental assessment with the pursuit of sustainability: "While the potential fit between environmental assessment and the pursuit of sustainability is good, few existing assessment processes manage to serve environmental objectives as well as they should" (Preface, xi). The core decision making criteria for sustainability enhance efforts to pursue sustainability by clarifying sustainability requirements and then translating them into a practical decision making tool. In order to be effective for the purpose of achieving sustainability, the preliminary, generic land use decision making criteria derived from Dobson (2000) must at a minimum fulfill Gibson et al.'s core decision making criteria for sustainability.

The results of Test I led to a revision of the preliminary, generic land use decision making criteria. Any gaps in the criteria were filled with particular requirements from Gibson et al.'s (2005) core decision making criteria for sustainability. The strengths and limitations of this revised, final set of criteria were investigated by applying them to the Waterloo Moraine land use case in the Region of Waterloo, Ontario (Test 2). In performing these evaluations, this study aims to contribute insights to the central predicament that exists within radical green political theory, which is to determine precisely how to achieve a sustainable society.

\section{Box I}

The essentials of the concept of sustainability

\section{The concept of sustainability is:}

- a challenge to conventional thinking and practice;

- about long- as well as short-term well-being;

- comprehensive, covering all the core issues of decision making;

- a recognition of links and interdependencies, especially between humans and the biophysical foundations for life;

- embedded in a world of complexity and surprise, in which precautionary approaches are necessary;

- a recognition of both inviolable limits and endless opportunities for creative innovation;

- about an open-ended process, not a state;

- about intertwined means and ends-culture and governance as well as ecology, society and economy;

- both universal and context dependent.

Source: Gibson et al. 2005, p. 62 
The above essentials of the concept of sustainability underpin Gibson et al.'s (2005) core decision making criteria for sustainability (see Box 2).

\section{Box 2}

\section{Core decision making criteria for sustainability}

\section{Socio-ecological system integrity:}

Build human-ecological relations to establish and maintain the long-term integrity of socio-biophysical systems and protect the irreplaceable life support functions upon which human as well as ecological well-being depends.

\section{Livelihood sufficiency and opportunity:}

Ensure that everyone and every community has enough for a decent life and that everyone has opportunities to seek improvements in ways that do not compromise future generations' possibilities for sufficiency and opportunity.

\section{Intragenerational equity:}

Ensure that sufficiency and effective choices for all are pursued in ways that reduce dangerous gaps in sufficiency and opportunity (and health, security, social recognition, political influence, etc.) between the rich and the poor.

\section{Intergenerational equity:}

Favour present options and actions that are most likely to preserve or enhance the opportunities and capabilities of future generations to live sustainably.

\section{Resource maintenance and efficiency:}

Provide a larger base for ensuring sustainable livelihoods for all while reducing threats to the long-term integrity of socioecological systems by reducing extractive damage, avoiding waste and cutting overall material and energy use per unit of benefit.

Socio-ecological civility and democratic governance: Build the capacity, motivation and habitual inclination of individuals, communities and other collective decision making bodies to apply sustainability requirements through more open and better informed deliberations, greater attention to fostering reciprocal awareness and collective responsibility, and more integrated use of administrative, market, customary and personal decision making practices.

\section{Precaution and adaptation:}

Respect uncertainty, avoid even poorly understood risks of serious or irreversible damage to the foundations for sustainability, plan to learn, design for surprise and manage for adaptation.

Source: Gibson et al., 2005, p. II5-117

\section{RADICAL GREEN POLITICAL THEORY}

Radical green political theory is just one shade of green political thought. It might be understood in relation to other shades of green political thought, which can be divided into two major groups that indicate their orientation towards decision making. One group advocates centralized authoritarian institutions for environmental problem-solving (Heilbroner, 1974; Ryle, 1988) while the other group would extend broad participation in the structures and processes employed by democratic institutions. This study is concerned with the latter group (Dryzek, 1987; Dobson, 2000; Smith, 2003; Eckersley, 2004; Paehlke and Torgerson, 2005). Both radical and reformist voices can be heard within the democratic strain of green political thought. For the purpose of this study, a brief description of some of the categorizations of green political thought will clarify the shade of green to which this study conforms.

Dobson's (2000) portrayal of radical green political thought depicts ecologism as its endoskeleton, bearing the weight of the radical green political agenda. From this standpoint, he distinguishes between "Green" politics, or ecologism, and "green" politics, or environmentalism. Ecologism seeks to transform the whole of society by confronting some of the dominant assumptions and values that support it, while environmentalism aims to alter existing political and economic practices using managerial style strategies and existing institutions. For green political thought to be "Green", then, it must challenge the "political, economic and social consensus that dominates contemporary life" (Dobson, 2000, p. 2). This distinction between Ecologism and environmentalism is what permits Dobson to argue that Ecologism exists as an independent political ideology.

Dryzek (1997) inserts some shades of green political thought into a categorization of the various environmental discourses that create the context within which environmental problems are approached. Environmental discourses essentially challenge the standards of industrialism and seek alternatives to these standards. According to Dryzek, these alternatives can be radical or reformist, prosaic or imaginative. Prosaic reactions, which may be radical or reformist, seek to solve environmental problems by using the established political and economic norms of industrialized societies. Imaginative solutions, which may be radical or reformist, aim to redefine the political and economic norms of industrialized society: "The environment is brought into the heart of society and its cultural, moral, and economic systems, rather than being seen as a source of difficulties standing 
outside these systems" (Dryzek, 1997, p. 13). The major difference between prosaic and imaginative solutions is that imaginative solutions highlight the interconnections and interdependencies that exist between the human and nonhuman worlds, while prosaic solutions define the environment as something separate from society.

Torgerson (1999) asserts that green political thought wavers between "systematic affirmation and systematic negation of the established order" (p. 145). Systematic affirmation is reformist because it proposes strategies that seek to make adaptive changes to contemporary, democratic institutions; systematic negation is radical because it seeks fundamental transformation of some aspects of society. Radical reformism exists somewhere between radicalism and reformism, calling for gradual change that leads to radical transformation. Still another shade, incremental reformism, rejects both radical change and systematic affirmation by calling for decision making processes that involve a plurality of stakeholders so that the relationships between civil society and the state are emphasized. Torgerson describes incremental radicalism as an even more decentralized approach than incremental reformism: “...breaking decisively with the epistemological presuppositions of the administrative mind" (p. 147).

One common feature among the above shades of green political thought is the problem of determining precisely what means should be used to achieve the sustainable society. This is indicative of the central tension that exists between the basic green desire to transform existing social, economic and political practices, and the practical (social, economic, political, ecological) implications of orchestrating such a transformation. Radicals and reformists, light green and dark green, seem to agree with Dobson (1990) at the end of the day: "if the Green movement is serious about staying Green and creating a sustainable life for us all...then current political strategies may not be sufficient" (p. 170).

The decision making criteria developed by this study have radical green underpinnings because they were derived from Dobson's (2000) depiction of ecologism. However, this study does not reject existing democratic institutions. Rather, it may inform them by outlining some criteria for land use decision making at the regional level which may draw more attention to new considerations and possibly to alternative decision making structures and processes.

\section{METHODS}

A set of preliminary generic land use decision making criteria was derived from three key chapters in Dobson's (2000) Green Political Thought: "Philosophical Foundations", "The Sustainable Society", and "Strategies for Green Change". These key chapters comprise the core of Dobson's discussion of the central components of ecologism. A critical review of these three chapters involved selecting specific elements of ecologism (concepts, theories, and strategies) for the development of the preliminary, generic land use decision making criteria. An element was selected if it was both central to ecologism and relevant to the socio-ecological concerns (social, economic and ecological) broadly associated with land use decision making.

The selected elements were first grouped according to the chapters from which they emerged. If a particular central element could be drawn from other important concepts, these were grouped together with the central element. The selected elements were then categorized according to the land use decision making concern or concerns (social, economic and ecological) to which they related. These three categories of concern are capable of presenting the full range of sustainability requirements. According to Gibson et al. (2005), they are “...conventional modern policy and disciplinary categories used to represent the main broad areas of concern for sustainability initiatives" (p. 94). Gibson et al. also assert, however, that these categories function more to separate and categorize than to demonstrate links and interdependencies. In order to highlight potential links and interdependencies a selected element was then listed under all concerns to which it related. Building on this categorization, the selected elements were grouped again according to the sustainability requirement to which they related. Gibson et al.'s sustainability requirement categories (socio-ecological system integrity, livelihood sufficiency and opportunity, etc.) were employed for this purpose.

The selected elements were then translated into a set of preliminary, generic land use decision making criteria. Gibson et al.'s (2005) sustainability requirement categories served as a guide in the translation process. For example, if particular selected elements of ecologism reflected Gibson et al.'s “socioecological system integrity" requirement, they were translated into a similar criterion for land use decision making. 
The strengths and limitations of the preliminary generic land use decision making criteria were investigated by evaluating them qualitatively, as a whole, against each of Gibson et al.'s (2005) core decision making criteria for sustainability (Test I). For example, Gibson et al.'s “socio-ecological system integrity" criterion entails building "human-ecological relations to establish and maintain the long-term integrity of socio-biophysical systems and protect the irreplaceable life support functions upon which human as well as ecological well-being depends" (p. II5). As a whole, the preliminary criteria fulfilled this criterion. Ecologism's ethical state of being requires the cultivation of an ecological consciousness as the foundation for more ecologically sensitive forms of behaviour (see Dobson, 2000, p. 46-5I). Ecologism's ethical code of conduct extends the boundaries of the ethical community around whole systems, including human and non-human entities (see Dobson, 2000, p. 40-46). Ecologism's ethical theory therefore reflects the type of human-ecological relations expressed by Gibson et al. Indeed, it is fair to presume that building human-ecological relations that support the long term integrity of socio-biophysical systems, etc. may be enabled, in part, by ecologism's ethical theory. Secondly, ecologism emphasizes the interdependencies and interconnections between human and non-human systems. It is therefore possible to speak of socioecological systems and to represent the parts of these systems as socio-biophysical or socio-ecological units.

The preliminary criteria derived from Dobson (2000) were revised so that any gaps were filled with content from Gibson et al.'s (2005) criteria. The results of Test I, for example, indicated that the preliminary criteria were, as a whole, insufficient in light of Gibson et al.'s intra- and intergenerational equity criteria. The preliminary criteria were therefore revised to include Gibson et al.'s social equity requirements.

The strengths and limitations of a revised, final set of generic land use decision making criteria were investigated by applying them to the case specific context of the Waterloo Moraine land use case (Test 2 ). To be effective in land use decision making for sustainability, the final criteria must, at a minimum, be capable of addressing the context specific, socioecological concerns in the subject land use case. Key concerns that were not addressed revealed where the criteria could be improved in this particular context.

The key concerns of the Waterloo Moraine land use case were determined through qualitative, face-toface interviews with citizens from a local community group, Citizens for the Protection of the Waterloo Moraine. The central questions posed by the principal researcher included:

When and why did you become involved in the Waterloo Moraine land use issue?

What, in your opinion, is the most important issue in the Waterloo Moraine land use case?

What, in your opinion, are the other important issues in the Waterloo Moraine land use case?

Will urban development on the Waterloo Moraine affect you personally? If so, how?

Secondary research included an analysis of Municipal and Regional Planning reports, letters to Council from concerned citizens, open house meeting minutes, environmental assessments, subdivision plans, and transportation studies. These documents supported primary research and revealed the Region's perspective on the key concerns. The story of the Waterloo Moraine land use issue and a detailed chronology of the main events in decision making were derived from these documents. Table I below provides a summary of the key concerns in the Waterloo Moraine land use case.

\section{WATERLOO'S WEST SIDE STORY}

The roots of the Waterloo Moraine land use issue reach back to 1985, when the Region of Waterloo's Revised Official Policies Plan (ROPP) indicated a need for additional lands designated "Urban" to supply residential land needs for population growth. This prompted land owners on the West Side of Waterloo to request deferral of the "Rural" designation on their lands in the ROPP. At this point in time, the Waterloo Moraine land use issue was part of the broader issue of development on the West Side of Waterloo. Key stakeholders in the Waterloo Moraine land use issue have always been developers, members of Regional and Municipal Councils, Regional and City staff, concerned citizens, community groups, academics, and the Grand River Conservation Authority.

From the beginning, the Region and the City of Waterloo were sensitive to the environmental issues on the West Side. They initiated the West Side Designation Study (WSDS) and the Laurel Creek Watershed Study (LCWS) in order to ensure that development on the West Side was both warranted and appropriate. The WSDS found that development of the West Side Lands was indeed required to 
accommodate a need for residential housing for anticipated population growth. The LCWS was assigned the task of developing a management plan for the Laurel Creek Watershed. These studies were in part a response to concerns raised by residents of the West Side and other citizens for their quality of life and the environmental integrity of the sensitive area. The required length of time to complete the above studies frustrated the developers, who claimed that the Region only wanted to delay the inevitable. In 1990, therefore, the developers requested that the ROPP designations be referred to the Ontario Municipal Board (OMB), a provincially-appointed tribunal that hears appeals on land use disputes. The OMB decided for the developers and soon the West Side Lands were officially designated "Urban".

The OMB's decision marked a dramatic shift in the direction of the Waterloo Moraine land use issue. Concerned citizens and community groups continued to campaign against the OMB's decision, claiming that development on the West Side would have negative impacts on the connectivity of adjacent forested lands, air quality, water quality and quantity, and wildlife. The Region and the City, however, began to initiate district plan reviews, transportation studies, sewage infrastructure studies, subwatershed studies, and class environmental assessments in preparation for development. A significant step for environmental protection was taken in 1993, when the Region incorporated the recommendations of the LCWS into the City of Waterloo's Official Plan to guide development on the West Side.

From about 1990 to the present, the Waterloo Moraine land use issue has been characterized by numerous submissions of subdivision draft plans by the developers, and numerous public meetings and open houses hosted by the Region or the City to gain public input into road and subdivision designs. Although many citizens remain pessimistic about the socio-ecological impacts of the proposed subdivisions, Regional and City Councils and the developers continue to push forward.

\section{I Waterloo West Side Lands}

The Region of Waterloo is situated in the southwestern corner of southern Ontario's Greater Golden Horseshoe (GGH), the fastest growing urban area in Canada. The cities, regional municipalities and counties in the GGH hug the southern tip of Lake Ontario, creating a horseshoe shape. The Region of Waterloo is one of the fastest growing communities in the GGH. Its current population, approximately
498000 , is expected to grow to over 729000 by 2031. Under the Province of Ontario's Places to Grow Act, the Places to Grow Growth Plan for the Greater Golden Horseshoe has highlighted the Region of Waterloo as one of many urban growth centers in the GGH to accommodate population growth and associated urban development.

The chief land use issue involves plans for three residential subdivisions at the westernmost boundary of Waterloo, a rural and agricultural area characterized by rolling hills and fragments of upland and lowland forests. The proposed subdivisions are particularly controversial because they impinge upon environmentally sensitive features of the landscape, including Provincially Significant Wetlands, a network of Environmentally Sensitive Policy Areas, the headwaters of Clair Creek, and the recharge soils of the Waterloo Moraine. The proposed subdivisions are situated on a portion of the Waterloo Moraine, a $736 \mathrm{~km} 2$ glacial moraine system with underlying aquifers that discharge into the Grand River, a major hydrological feature of the Grand River Watershed in southern Ontario. The waters of the Moraine and the Grand River are tapped by the Region of Waterloo for its water supply. Water quantity and quality have therefore emerged as major issues in the Region, especially in the context of the directives of Ontario's Places to Grow Growth Plan.

\subsection{The Planning Context}

The legislative and policy framework guiding the subdivision development approval process in the Region of Waterloo begins with the Ontario Planning Act and the Ontario Environmental Assessment Act. The Region of Waterloo's Regional Official Plan (ROP) and the City of Waterloo's Official Plan (OP) must be consistent with the Ontario Planning Act and the Provincial Policy Statement, provincial policy that provides direction on matters of land use planning and development. Regional and Municipal OPs establish planning policies and goals to guide and control overall development and growth, including infrastructure and services planning, future land use planning, and zoning by-laws. The City's OP is obligated to be in compliance with the Regional OP. The Ontario Planning Act prescribes criteria that must be applied when a subdivision application is considered for approval. These criteria specify that any application for development must conform to the Ontario Planning Act and Regional or Municipal Official Policy Plans. 
EUE • Radical Green Political Theory • a-70

Table I

Summary of key concerns in the Waterloo Moraine land use case

\begin{tabular}{|c|c|}
\hline Type of concern & Summary \\
\hline Urban growth & $\begin{array}{l}\text { - Maintenance of rural identity } \\
\text { - Maintenance of overall quality of life } \\
\text { Maintenance of tradition of stewardship of natural features }\end{array}$ \\
\hline Water quantity and quality & $\begin{array}{l}\text { - Maintenance of pre-development condition of surface water flow } \\
\text { - Maintenance of pre-development condition of recharge soils } \\
\text { - Maintenance of pre-development recharge levels to the deep } \\
\text { aquifer } \\
\text { - } \quad \text { Long term monitoring of the Clean Water Collection system } \\
\text { Maintenance of pre-development quality of surface water and } \\
\text { groundwater } \\
\text { Maintenance of dimensions of the clay till cap }\end{array}$ \\
\hline Traffic & $\begin{array}{l}\text { - } \\
\text { - Noir quality } \\
\text { - Impollution } \\
\text { Sensitive Policy Areas } \\
\text { - Impact of road salt on water quality } \\
\text { Appropriate road design }\end{array}$ \\
\hline $\begin{array}{l}\text { Ecological integrity of network of } \\
\text { Environmentally Sensitive Policy Areas }\end{array}$ & $\begin{array}{l}\text { - Maintenance of connectivity } \\
\text { - Ecological integrity of Provincially Significant Wetlands } \\
\text { - Ecological integrity of Environmentally Sensitive Policy Areas } \\
\text { Impact of development on flora and fauna }\end{array}$ \\
\hline Appropriate development & $\begin{array}{l}\text { Appropriate development of lands according to Regional } \\
\text { environmental policy for the West Side }\end{array}$ \\
\hline Procedural, Structural, Economic & $\begin{array}{l}\text { - Adherence to Ontario Planning Act } \\
\text { - Adherence to Regional Official Plan and City of Waterloo Official } \\
\text { Plan } \\
\text { - Adherence to structure of decision making for Plan of Subdivision } \\
\text { Approval } \\
\text { - Finances for infrastructure studies } \\
\text { Finances for Environmental Assessments }\end{array}$ \\
\hline
\end{tabular}


First passed in 1975, Ontario's Environmental Assessment Act (EAA) mandates that municipalities undertake an environmental assessment (EA) for enterprises, activities, proposals, plans, and programs. These often include public infrastructure developments (roads and highways), waste management facilities, sewage and water facilities, and transit works. Any of these undertakings, however, may be exempt from the EA process with approval from the Minister of the Environment. Individual citizens may request that the Minister direct a private project to undertake an EA subject to the requirements of the EAA. Most municipal projects, however, are not required to undergo an individual EA. Instead, they follow a streamlined process under the provisions of a Class EA. These types of projects are usually routine and predictable: municipal roads, sewage and water infrastructure, highway construction and maintenance, forest management activities, and works undertaken by conservation authorities.

In 2005, the Places to Grow Act received Royal Assent. This Act allows the Government of Ontario to designate any area of land in the Province as a growth plan area. It reflects the intentions of the Provincial Policy Statement and ensures that land use within any growth plan area is subject to the conformity requirements of the Ontario Planning Act. Additionally, Official Plans must conform to the Growth Plan. Under the legislative framework of the Places to Grow Act, the Government of Ontario released the Growth Plan for the Greater Golden Horseshoe.

\section{RESULTS}

A noted in section 2, a set of preliminary generic land use decision making criteria was derived from three key chapters in Dobson's (2000) Green Political Thought: "Philosophical Foundations", "The Sustainable Society", and "Strategies for Green Change". A critical review of these chapters involved selecting specific elements of ecologism (concepts, theories, and strategies) for the development of the preliminary criteria. An element was selected if it was both central to ecologism and relevant to the socio-ecological concerns (social, economic, ecological) broadly associated with land use decision making. Table 2 depicts the first categorization of the selected elements according to the chapters from which they emerged.

Below is a summary of the three key chapters, emphasizing the elements selected for development of the preliminary, generic land use decision making criteria.

\section{I The Philosophical Foundations of Ecologism}

Dobson (2000) asserts that ecologism professes a particular set of reasons for why we should care for the environment-radical ecological reasons. To defend these reasons, ecologism has armed itself with twentieth century physics, the science of ecology, and the philosophy of deep ecology.

The twentieth century's scientific understanding of the universe has a particular set of implications for ecologism. Ecologism, for example, rejects discrete atomism's hierarchical arrangement of the world and instead embraces the view that all of the particles that comprise the universe are equally important. By extension, then, ecologism professes egalitarianism. The emphasis on the importance of the relationships and the interactions between particles at the subatomic level has led ecologism to adopt an understanding of the world from a systems point of view. A systems understanding of the world entails, among other things, recognizing the interconnections and interdependencies that exist among and between ecological and human systems. This view helps to generate a sense of equality: "...each item is held to be necessary for the viability of every other item. In this view no part of the natural world is independent and therefore no part can lay claim to "superiority"' (Dobson, 2000, p. 24).

The science of ecology provides ecologism with lessons from nature that underpin its prescriptions for social and political arrangements. Ecology is concerned with the way plants and animals interact with each other and their surrounding environments. The interrelationships, interdepen-dencies and interconnections of the non-human natural world are emphasized. Plants, animals, and their environments are understood as interacting parts of a system rather than discrete entities that are spatially and temporally independent and isolated from one another. Nature, then, also professes the principle of equality among human beings and human beings and the non-human world.

The similarities between the science of ecology and twentieth-century physics clearly make them allies against a hierarchical, atomistic understanding of the world. Dobson (2000) highlights three ecological principles with particular significance to ecologism's prescriptions for the sustainable society: diversity, interdependence, and longevity. 
Table 2

Selected central elements of ecologism categorized according to key chapters in Dobson's (2000) Green Political Thought

\section{Chapter in Dobson's (2000) Green Political Thought \\ Selected elements of ecologism}

"Philosophical Foundations"
- Egalitarianism (socio-ecological, biophysical, underpinned by an ecological principle of interdependence and an ethical theory)

- A systems understanding of the world (emphasizes cross-scale, socio-ecological interdependencies and interconnections)

- Ecological principle of diversity (supports toleration, resilience, democracy)

- Ecological principle of longevity (supports reverence for the natural world)

- Anti-anthropocentrism (underpinned by a principle of intrinsic value and an ethical theory)

Shift in onus of justification from those who want to preserve the non-human world to those who wish to interfere with its preservation (underpinned by an ethical theory)

"The Sustainable Society"

- Carrying capacity (underpinned by the limits to growth thesis and the need to lower consumption)

- $\quad$ Bioregionalism (small, decentralized, self-reliant communities)

Precautionary approach towards technology (underpinned by the limits to growth thesis)

"Strategies for Green Change"

- Participatory democracy

Decentralized communities
The ecological principle of diversity supports toleration, resilience and democracy; interdependence supports ecologism's egalitarian orientation; and ecological longevity supports ecologism's reverence for the natural world. Egalitarianism is carried into ecologism's ethical theory, which includes a code of conduct and a state of being.

Ecologism's ethical theory is underpinned by the philosophy of deep ecology. The term "deep ecology" was coined by Arne Naess, a Norwegian philosopher, in the early 1970s. Naess distinguishes between the "shallow" and "deep" ecology movements: shallow ecology advocates care for the environment because it has instrumental value for human beings, while deep ecologists assert that we should care for the environment for its own sake. This latter notion of care for the environment is what Dobson (2000) calls Naess' principle of intrinsic value and it undergirds ecologism's ethical code of conduct. Following Naess' principle of intrinsic value, the boundaries of ecologism's ethical community are extended around species and ecosystems as well as human beings. Ecologism's environmental ethic, then, applies to the whole environment, rather than just to humans or just to animals. It also subscribes to the principle of biospherical egalitarianism - total equality between natural parts.

The philosophy of deep ecology supports ecologism's prescription for an ethical state of being. Key to this ethic is the hope that the cultivation of an ecological consciousness will be the foundation for a more ecologically sensitive ethic with more ecologically sensitive forms of behaviour. Deep ecology, then, promotes a consciousness of identification with the nonhuman world as the preferable foundation for a new code of conduct. Its adherents hope that this new code of conduct will shift the onus of justification from those 
who want to preserve the non-human world to those who wish to interfere with its preservation.

The final component of the philosophical foundations of ecologism to be discussed is the centrality of the principle of anti-anthropocentrism: "If there is one word that underpins the whole range of radical green objections to current forms of human behavior in the world, it is probably 'anthropocentrism'..." (Dobson, 2000, p. 5I). Ecologism aims to place humans on to the green political agenda in a non-anthropocentric way. Dobson (2000) therefore distinguishes between a weak, or "human-centred" and a strong or "humaninstrumental" understanding of anthropocentrism. He asserts that both are important aspects on the agenda of ecologism. For example, an idea or concept, etc., may be human-centred but this does not make the idea or concept, etc., essentially human-instrumental. This is because the former is unavoidable for humans; we cannot create any system apart from the context of our social and political cultures. Our desire to care for the nonhuman world is therefore human-centred simply because it is a human idea, but our desire to care for the nonhuman world as part of a deep respect and admiration for all creatures is not necessarily human-instrumental. According to this logic, the deep ecological notion that the non-human world has intrinsic value is essentially human-centered but it is not human-instrumental.

\subsection{The Sustainable Society}

The radical green prescription for change involves a particular set of ingredients for a sustainable society underpinned by the limits to growth thesis. The limits to growth thesis to which radical greens subscribe arose in part from the Club of Rome's 1972 Limits to Growth report and subsequent publications. The thesis supports the fundamental green belief that the Earth is finite and that it possesses real limitations to growth. These limits and their associated scarcity define key parameters of a distinct, radical green sustainable society. Such a society, according to Dobson (2000), also contains a particular set of political-institutional arrangements and social and ethical norms. In part, they stem from the dark-green claim that certain ways of living are more sustainable than others. First and foremost, the sustainable society prescribed by ecologism is democratic and Dobson leads us through this society from the perspective of the fundamental green urge to reduce consumption. From this perspective, the principal aspects of the radical green Utopia unfold: the theory of need, recommendations for population levels, attitudes towards technology, sustainable sources of energy, and the self-reliant community.
The need to reduce consumption is a consequence of the radical green argument for a decrease in throughput, the components of which include "resource depletion, production, depreciation (involving consumption) and pollution" (Dobson, 2000, p. 77). For radical greens, the consumption problem is paramount in industrialized societies because it exacerbates the other components of throughput. If consumption is reduced, a reduction in the other components of throughput will follow. For ecologism, reducing consumption eventually leads to the development of a theory of need, a controversial undertaking because of the difficulty in distinguishing between needs and wants, and developing a universal definition of needs and wants. A potential settling of these challenges might be found in Dobson's recognition that needs and wants are embedded in cultural contexts. Overall, the aim is to decide what we can do without.

Reducing consumption significantly is likely to involve reducing the number of people on the planet, another contentious green idea. This desire for population control is firmly grounded in the fact that present and future population levels are unsustainable. That said, greens recognize the inadequacy of adopting a simplistic plan for across-the-board reductions; certain countries consume more than others and certain areas of the world are more populated than others. Additionally, there are disagreements over exactly how many people the Earth can sustain and what to do with the excess. Greens assert that population control should be negotiated rather than imposed. Radical green strategies for population control, for example, include tax breaks for families with fewer than two children and equal opportunities for women, to name a few.

Radical greens are highly critical of the "technological fix". This aversion towards modern technology stems from the fundamental belief that no amount of technological wizardry will allow humankind to overcome the problems associated with exponential growth. Technology may only prolong the inevitable or transfer our environmental problems from one area to another. The radical green position, then, holds that societies should adjust their social practices to the natural limits that surround them. Dobson (2000) is quick to assert, however, that although radical greens prefer moral solutions and changes in attitude and behaviour, their general attitude towards technology is one of uncertainty and precaution. The use of one technological device or another, therefore, depends on the kind of technology in question, the processes involved in its production, the potential for participative human control, and the associated impacts on the environment. Overall, the radical green orientation towards technology reflects its 
unwavering concern with the finite capacity of the Earth. This narrow focus brings to the foreground of the technology debate the dark-green push for an overall reduction in consumption as the best solution to the absolute scarcity of resources associated with the limits to growth thesis.

Small, decentralized, self-reliant communities are key components of the dark-green answer to the politicalinstitutional implications of the sustainable society. According to Dobson (2000), the concept of bioregionalism is the most ecologically correct framework within which these communities might be organized. Central to the concept of bioregionalism is the principle of living according to the ecological characteristics of the place where we live. Sale (1985) defines bioregionalism as a region governed by nature rather than legislature. Living bioregionally involves identifying bioregional boundaries within which individuals would be members of communities. Understanding the bioregional paradigm, however, is much more complex and Sale begins to walk his readers through this paradigm by highlighting the differences in four key aspects between bioregionalism and the dominant paradigm of industrialized societies: scale, economy, polity, and society.

\subsection{Radical Green Strategies for Change}

This study is concerned with the practical implications of radical green political theory in the context of the Waterloo Moraine land use issue; it aims to contribute knowledge to the predicament that exists within radical green political theory of precisely how to achieve the sustainable society. Although ecologism is a classic ideology in that it contains both a critique of present socio-political arrangements and a prescription for the future, there has been little thinking, until recently, on how to achieve the ends it desires. Nevertheless, ecologism does contain strategies for social change.

A major role of green movements is to influence the legislative process through lobbying elected political representatives. But at this point, a major problem arises for radical greens. The contentious issue is whether radical green ends can be realized through contemporary democratic institutions. Dobson (2000) describes the Western world's political institutional principle of representative democracy as one such practice that radical greens would replace with participatory democracy, which is inclusive of the stakeholders involved in a particular issue. It follows that the activities of green parties in the parliamentary system risk watering down the radical green agenda to the point of dilution beyond recognition. Dobson provides one possible route around this problem; the radical green agenda is such that not all of its prescriptions for social change can be met at once; therefore, it is better to bring about a few changes through existing political institutions than none at all. Overall, then, radical green strategies do include liberal-democratic political institutions, but they risk severely compromising the radical green agenda.

Community living as a new social formation is central to ecologism's vision of the sustainable society. They involve care for the well-being of the community rather than the individual. The decentralized community construct is seen as the ideal institutional context for bringing about practices that are environmentally sustainable.

\subsection{Categorization of Selected Elements According to Socio-Ecological Concerns}

The selected elements were further categorized according to the land use decision making concern or concerns (social, economic, ecological) to which they related. Table 3 depicts this second categorization.

It is important to note that the central concept of egalitarianism was restricted to the social and ecological categories and did not extend to the economic. This decision was based on a literal interpretation of ecologism, i.e. Dobson's (2000) description of egalitarianism emphasizes the interconnections and interdependencies between humans and the non-human world; the particulars of how this might translate into an economic theory, or the specifics about how gaps between the rich and poor should be treated are not articulated. In keeping with a literal interpretation of Dobson's depiction of egalitarianism, then, the central concept of egalitarianism was confined to the social and ecological categories of concern.

\subsection{Using Gibson et al. (2005) Sustainability Criteria as a Guide in Translation}

Gibson et al. (2005) core decision making criteria for sustainability served as a useful guide in the process of translation from selected central elements, as organized in Table 3, to land use decision making criteria. The selected elements were categorized a third time according to Gibson et al.'s sustainability requirement categories (Table 4). 
EUE • Radical Green Political Theory • a-75

Table 3

Selected elements categorized according to type of socio-ecological concern(s) broadly associated with land use decision making

Social

Ecologica
- Egalitarianism (biophysical, underpinned by ecological principle of interdependence and ethical theory)

- A systems understanding of the world (emphasizes cross-scale, socio-ecological interdependencies and interconnections)

- Ecological principle of diversity (supports toleration, resilience, democracy)

- Ecological principle of longevity (supports reverence for the natural world)

- Anti-anthropocentrism (underpinned by a principle of intrinsic value and an ethical theory)

- Shift in onus of justification from those who want to preserve the non-human world to those who wish to interfere with its preservation (underpinned by an ethical theory)

- Carrying capacity (underpinned by the limits to growth thesis and the need to lower consumption)

- $\quad$ Bioregionalism (small, decentralized, self-reliant communities)

- Precautionary approach towards technology (underpinned by the limits to growth thesis)

- Participatory democracy

Decentralized communities

\begin{tabular}{ll}
\hline Economic & Bioregionalism (small, decentralized, self-reliant communities)
\end{tabular}

- Egalitarianism (biophysical, underpinned by the ecological principle of interdependence and an ethical theory)

- A systems understanding of the world (emphasizes cross-scale, socio-ecological interdependencies and interconnections)

- Ecological principle of diversity (supports toleration, resilience, democracy)

- Ecological principle of longevity (supports reverence for the natural world)

- Anti-anthropocentrism (underpinned by a principle of intrinsic value and an ethical theory)

- Carrying capacity (underpinned by the limits to growth thesis and the need to lower consumption)

Bioregionalism (small, decentralized, self-reliant communities) 
EUE • Radical Green Political Theory • a-76

Table 4

Categorization of selected elements according to Gibson et al.'s (2005) sustainability requirements

\begin{tabular}{|c|c|c|}
\hline $\begin{array}{l}\text { Sustainability requirement } \\
\text { (Gibson et al., 2005) }\end{array}$ & $\begin{array}{c}\text { Socio-ecological concern(s) } \\
\text { (see Table } 3 \text { ) }\end{array}$ & $\begin{array}{c}\text { Selected elements of ecologism } \\
\text { (see Table 3) }\end{array}$ \\
\hline \multirow[t]{5}{*}{ Socio-ecological system integrity } & Social, ecological & $\begin{array}{l}\text { - A systems understanding of the } \\
\text { world (emphasizes cross-scale, } \\
\text { socio-ecological interdependencies } \\
\text { and interconnections) }\end{array}$ \\
\hline & Social, ecological & $\begin{array}{l}\text { - Ecological principle of diversity } \\
\text { (supports toleration, resilience, } \\
\text { democracy) }\end{array}$ \\
\hline & Social, ecological & $\begin{array}{l}\text { - Ecological principle of longevity } \\
\text { (supports reverence for the natural } \\
\text { world) }\end{array}$ \\
\hline & Social, ecological & $\begin{array}{l}\text { - Anti-anthropocentrism (underpinned } \\
\text { by a principle of intrinsic value and } \\
\text { an ethical theory) }\end{array}$ \\
\hline & Social & $\begin{array}{l}\text { Shift in onus of justification from } \\
\text { those who want to preserve the } \\
\text { non-human world to those who wish } \\
\text { to interfere with its preservation } \\
\text { (underpinned by an ethical theory) }\end{array}$ \\
\hline Livelihood sufficiency and opportunity & - & - \\
\hline Intragenerational equity & - & - \\
\hline Intergenerational equity & - & - \\
\hline \multirow[t]{4}{*}{ Resource maintenance and efficiency } & Social, ecological & $\begin{array}{l}\text { Ecological principle of diversity } \\
\text { (supports toleration, resilience, } \\
\text { democracy) }\end{array}$ \\
\hline & Social, ecological & $\begin{array}{l}\text { Ecological principle of longevity } \\
\text { (supports reverence for the natural } \\
\text { world) }\end{array}$ \\
\hline & Social, ecological & $\begin{array}{l}\text { - Carrying capacity (underpinned by } \\
\text { the limits to growth thesis and the } \\
\text { need to lower consumption) }\end{array}$ \\
\hline & Social, economic, ecological & $\begin{array}{l}\text { Bioregionalism (small, decentralized, self- } \\
\text { reliant communities) }\end{array}$ \\
\hline \multirow[t]{3}{*}{$\begin{array}{l}\text { Socio-ecological civility and democratic } \\
\text { governance }\end{array}$} & Social, ecological & $\begin{array}{l}\text { Egalitarianism (biophysical, } \\
\text { underpinned by the ecological } \\
\text { principle of interdependence and an } \\
\text { ethical code of conduct) }\end{array}$ \\
\hline & Social & - Participatory democracy \\
\hline & Social & Decentralized communities \\
\hline Precaution and adaptation & Social & $\begin{array}{l}\text { Precautionary approach towards } \\
\text { technology (underpinned by the limits to } \\
\text { growth thesis) }\end{array}$ \\
\hline Immediate and long-term integration & $\overline{-}$ & - \\
\hline
\end{tabular}


Gibson et al.'s (2005) livelihood sufficiency and opportunity, intra- and intergenerational equity, and immediate and long-term integration criteria were not represented by the selected central elements of ecologism. Table 4 reveals that the majority of the selected elements fall under the socio-ecological system integrity criterion. The results of this categorization begin to suggest that ecologism is fundamentally orientated towards the non-human world. This particular orientation is perhaps a consequence of ecologism's aim to reject and transform the status quo by placing the non-human world at the centre of its ethical theory. Test I elaborates on this finding.

\subsection{Preliminary, Generic Land Use Decision Making Criteria Derived from Dobson (2000)}

Box 4 summarizes the preliminary, generic land use decision making criteria derived from Dobson's (2000) depiction of ecologism. The criteria are organized according to the sustainability requirement categories used by Gibson et al. (2005). The criteria that were not expressed by the selected elements of ecologism (livelihood sufficiency and opportunity, intragenerational equity, intergenerational equity, and immediate and long-term integration) were not incorporated at this stage.

The term "socio-ecological" was used throughout criteria development as an expression of ecologism's intention to recognize the links and interdependencies between human and non-human systems.

The selected elements of ecologism that were categorized according to Gibson et al.'s (2005) "socioecological system integrity" criterion in Table 4 were translated into three different land use decision making criteria. The first criterion integrates the elements related to a systems understanding of the world and the ecological principles of diversity and longevity. These three elements are complementary and well suited to the discipline of land use decision making; they deal with socio-ecological systems, ecological principles that are important to the integrity of these systems, and a particular approach to understanding them.

The second and third criteria in the "socioecological system integrity" category were determined to be stand-alone criteria. The criterion dealing with the "onus of justification" is well suited to decision making that involves trade-offs. Gibson et al. (2005) recognize that conflicts, which inevitably lead to compromise, may arise between the valued components of an ecosystem. To ensure that these conflicts do not sacrifice the goal of sustainable development, they developed a set of trade off rules (p. |22-|4I) to guide decision making. In a similar way, the criterion that deals with the "onus of justification" may guide land use decision making during times of conflict and compromise. Ecologism's antianthropocentrism was translated into a criterion that expresses Dobson's (2000) distinction between a weak, or "human-centred" and a strong or "humaninstrumental" understanding of anthropocentrism.

The elements related to carrying capacity and bioregionalism were translated into one criterion that expresses Gibson et al.'s “resource maintenance and efficiency" requirement; both elements entail prescriptions for natural resource extraction and material consumption. The complementary elements of egalitarianism, participatory democracy, and decentralized communities were combined into once criterion as an expression of Gibson et al.'s (2005) "civility and democratic governance" criterion. Ecologism's precautionary approach to the use of technology was translated into a criterion that expresses Gibson et al.'s (2005) "precaution and adaptation" 4.7. Results of Test I: Overall Strengths and Limitations of Preliminary, Generic Land Use Decision Making Criteria criterion.

\subsection{Results of Test I: Overall Strengths and Limitations of Preliminary, Generic Land Use Decision Making Criteria}

The strengths and limitations of the preliminary generic land use decision making criteria were investigated by evaluating them, as a whole, against each of Gibson et al.'s (2005) core decision making criteria for sustainability. All together, the preliminary criteria did not fulfill Gibson et al.'s criteria pertaining to livelihood sufficiency and opportunity, intra- and intergenerational equity, socio-ecological civility and democratic governance, precaution and adaptation, and immediate and long-term integration. This weakness is a consequence of ecologism's orientation towards the natural world. For example, nowhere does Dobson's portrayal of ecologism speak of "sufficiency and opportunity" or "equity" as end points in its ethical theory. Moreover, although ecologism can speak of maintaining and protecting socio-biophysical longevity and diversity, it does not explicitly reserve a space for the consideration of the capability of future generations to live sustainably. Future generations and sustainability are implied by ecologism's adherence to these ecological principles. 


\section{Box 4}

Summary of preliminary, generic land use decision making criteria, using Gibson et al.'s (2005) sustainability requirement categories as a guide

\section{Socio-ecological system integrity}

Land use decision making must adopt a systems approach that is oriented towards maintaining socio-ecological diversity, respecting the temporal and spatial interdependencies within and between socio-biophysical systems, and protecting the longevity of the socio-biophysical systems involved in each case.

On matters of conflict and compromise, the onus of justification must be placed on those participants who wish to interfere with the maintenance of socio-ecological diversity, respecting the temporal and spatial interdependencies within and between socio-biophysical systems, and the protection of the longevity of the socio-biophysical systems involved.

Land use decision making must work towards outcomes that are not human-instrumental.

\section{Resource maintenance and efficiency}

Land use decision making must work towards the development of small, decentralized, self-reliant communities that are defined by bioregional boundaries and respect the limits of immediate and surrounding socio-ecological systems so that the carrying capacity of a given area is not exceeded by land use, population level, and resource consumption and extraction.

\section{Socio-ecological civility and democratic governance}

All of the phases, structures and processes of land use decision making must serve to enhance the development of decentralized communities, and must be oriented towards inclusive and equal consideration, engagement, and representation of the socio-biophysical units in the systems involved in each case.

\section{Precaution and adaptation}

During all phases of land use decision making, decision makers must adopt a precautionary approach to the use of technology in land use matters, including pre-construction, construction, and post-construction phases. 
However, the lack of explicit recognition of future human generations emphasizes ecologism's bias towards the non-human world. This orientation limits the capacity of the preliminary, generic criteria to acknowledge the broad, human-centred, socioeconomic and political factors in environmental problems (distribution of resources, disparities between the rich and poor, etc.). It also limits the criteria's ability to address the finer, human-oriented details related to precaution and adaptation in decision making, and the social dynamics in democratic governance. Gibson et al.'s (2005) "socio-ecological civility and democratic governance" criterion, for example, recognizes some of the dynamics of participatory decision making processes, including, to name a few, the distribution of information and the nature of deliberations. But ecologism's desire for inclusive and equal consideration, engagement and representation are geared towards protecting the non-human world; therefore, they neglect the finer details in participatory decision making.

In one major aspect, however, the land use criteria based on ecologism go above and beyond Gibson et al.'s (2005) core criteria. Ecologism's ethical theory extends the moral community to incorporate non-humans and it explicitly injects human beings into the natural world; therefore, it is impossible to separate human well being from ecological well being. This connection of the human and ecological realms is supported further by ecologism's belief in the science of ecology and systems thinking. In this way, the preliminary criteria can consistently speak of representing the human and ecological and biophysical components of a system as units - as functional, socio-ecological or socio-biophysical constituents within a whole system - with interests that are necessary for the integrity of the socio-ecological unit.

At times, Gibson et al.'s (2005) criteria do not reflect this fusion. For example, the principle of intragenerational equity might be strengthened by ecologism's ethical theory by explicitly including the non-human world in this principle. Similarly, the principle of intergenerational equity might be strengthened if the opportunities and capabilities that it wishes to preserve or enhance explicitly embrace the non-human world-of future socio-ecological generations. Ecologism's ethical theory, therefore, which extends the moral community around nonhumans, is its overarching strength in the context of land use decision making for sustainability.

It may be that Gibson et al.'s (2005) criteria are intended for a different audience than ecologism; therefore, it may not be fair to ask the land use decision making criteria based on ecologism to fulfill Gibson et al.'s criteria. As an ideology, ecologism is aimed at the transformation of whole societies, while Gibson et al.'s criteria are oriented towards a particular sector or sectors of societies around the world, i.e. environmental assessment practitioners and public decision making bodies. Both, however, are concerned with sustainability and this common goal underlies the appropriate use of Gibson et al.'s criteria as a test for the criteria developed by this study.

The preliminary generic land use decision making criteria were revised to fulfill Gibson et al.'s (2005) core decision making criteria for sustainability. This was accomplished by incorporating text from Gibson et al.'s criteria. Again, the categories in the revised criteria were borrowed from Gibson et al.'s core decision making criteria for sustainability. Box 5 presents the revised, final generic land use decision making criteria derived from both Dobson (2000) and Gibson et al.

\subsection{Results of Test 2: Overall Strengths and Limitations of Final Generic Land Use Decision Making Criteria}

Test I revealed significant gaps in the preliminary generic criteria in light of Gibson et al.'s (2005) core decision making criteria for sustainability. Like environmental assessment cases, however, generic land use decision making criteria need to be specified for the particulars of the case and context. The practical strengths and weaknesses of the final, generic land use decision making criteria were therefore investigated by applying them to the case specific context of the Waterloo Moraine land use issue. To be effective in land use decision making for sustainability, the final criteria as a whole must, at a minimum, address the key concerns in the subject land use case.

Results of test 2 indicated that the final criteria did not address concerns related to the procedural, structural, and economic issues in the subject land use issue. Rather, the final generic criteria were oriented towards broad socio-economic and political issues, such as the distribution of resources, class divisions, and the capability of future generations to live sustainably. Specifically, the revised criteria did not address the socio-ecological implications of Regional and Municipal concerns to follow the legislative planning framework. This is significant in light of the importance of the Ontario Municipal Board hearing for the future of the Waterloo Moraine land use case. 
Box 5

Summary of revised, final generic land use decision making criteria derived from Dobson (2000) and Gibson et al. (2005)

\begin{abstract}
Socio-ecological system integrity
Land use decision making must adopt a systems approach that is oriented toward maintaining socio-ecological diversity, respecting the temporal and spatial interdependencies within and between socio-biophysical systems, and protecting the longevity of the socio-biophysical systems involved in each case.

During times of conflict and compromise, the onus of justification must be placed on those participants who wish to interfere with the maintenance of socio-ecological diversity, respecting the temporal and spatial interdependencies within and between socio-biophysical systems, and the protection of the longevity of the socio-biophysical systems involved.
\end{abstract}

Land use decision making must work towards outcomes that are non-human-instrumental.

\title{
Livelihood sufficiency and opportunity
}

Land use decision making must "ensure that everyone and every community has enough for a decent life and that everyone has opportunities to seek improvements in ways that do not compromise future generations' possibilities for sufficiency and opportunity" (Gibson et al., 2005).

\section{Intragenerational equity}

Land use decision making must "ensure that sufficiency and effective choices for all are pursued in ways that reduce dangerous gaps in sufficiency and opportunity (and health, security, social recognition, political influence, etc.) between the rich and the poor" (Gibson et al., 2005).

\section{Intergenerational equity}

Land use decision making must "favour present options and actions that are most likely to preserve or enhance the opportunities and capabilities of future generations to live sustainably" (Gibson et al., 2005).

\section{Resource maintenance and efficiency}

Land use decision making must work towards the development of small, decentralized, self-reliant communities that are defined by bioregional boundaries and respect the limits of immediate and surrounding socio-ecological systems so that the carrying capacity of a given area is not exceeded by land use, population level, and resource consumption and extraction.

\section{Socio-ecological civility and democratic governance}

All of the phases, structures and processes of land use decision making must be oriented towards inclusive and equal engagement and representation of the socio-biophysical units in the systems involved in each case and must build the capacity, motivation and habitual inclination of individuals, communities and other collective decision making bodies to apply sustainability requirements through more open and better informed deliberations, greater attention to fostering reciprocal awareness and collective responsibility, and more integrated use of administrative, market, customary and personal decision making practices.

\section{Precaution and adaptation}

During all phases of land use decision making, decision-makers must adopt a precautionary approach to the use of technology, respect uncertainty, avoid even poorly understood risks of serious or irreversible damage to the foundations for sustainability, plan to learn, design for surprise and manage for adaptation.

Immediate and long-term integration Land use decision making must "apply all principles of sustainability at once, seeking mutually supportive benefits and multiple gains" (Gibson et al., 2005). 
Budget constraints were also unaddressed. Fiscal issues in the Waterloo Moraine case included Regional and Municipal concerns for funds for multiple infrastructure studies and environmental assessments. The Region charged the developers for these studies, which is permitted under the Development Charges Act. This was a significant move because, in order for the Region to receive funds from the developers, the lands had to be zoned "Urban" in the ROP. These findings support the results of the first test: ecologism's bias towards the non-human world limits its ability to acknowledge the socio-economic and political factors in land use decision making. The results also suggest that the final generic criteria are too broad for some of the finer details related to land use decision making.

Ecologism's theme of anti-anthropocentrism may also underlie its lack of explicit attention to stakeholder concerns for maintenance of cultural identity and tradition. This neglect may be indicative of ecologism's wish to dismantle and reconstruct the paradigms that dominate industrialized societies. Again, in this manner, cultural identity and tradition are implicitly recognized as a part of the problem and a part of the solution. Both are also implicitly included in ecologism's desire to protect socio-ecological systems from development. In spite of this, the lack of explicit attention to cultural identity and tradition may work towards rendering radical green political theory ineffective in countries where cultural identity and tradition are complicated by myriad factors, such as colonialism and ongoing foreign exploitation of natural resources.

The strengths of the final generic criteria also support the first test findings: ecologism's ecological principles, systems thinking, and ethical theory underpin the fusion of socio-ecological systems in decision making. The criteria consistently addressed issues pertaining to water quality and quantity, pollution, and the integrity of the key features of the Waterloo Moraine and surrounding ecological systems.

\section{CONCLUSION}

The evaluation of the preliminary criteria revealed that ecologism is inadequate in its capacity to acknowledge many of the socio-economic and political factors in achieving sustainability; they did not fully address Gibson et al.'s (2005) criteria pertaining to sufficiency and opportunity, disparities between the rich and the poor, the capabilities of future generations to live sustainably, participatory decision making, precaution and adaptation, and applying all principles of sustainability at once. This inadequacy is due to ecologism's fundamental orientation towards the non-human world, which is indicative of its desire to reject and transform the status quo. However, ecologism's ethical theory, which includes the principle of biospherical egalitarianism, its systemic understanding of the world, and the importance of the science of ecology to its prescriptions for social and political arrangements, permit the criteria to represent the human, ecological and biophysical components of a system as units-as functional, socio-ecological or socio-biophysical constituents within a whole system. Human and non-human well being considerations are therefore fused in decision making.

The evaluation of the revised, final land use decision making criteria revealed similar strengths and limitations. The fusion of socio-ecological or sociobiophysical systems, underpinned by ecologism's emphasis on ecological principles, systems thinking, and its ethical theory, surfaced again as a major strength; the final generic land use decision making criteria accommodated most of the key concerns in the subject land use case. The concerns that were not addressed support the results of the first test: ecologism's orientation towards the non-human world rendered it inadequate in its capacity to address the human-centered procedural, structural, and economic factors in land use decision making. The final generic criteria were not able to address the barriers to sustainable development imposed by the Ontario Municipal Board, Official Plans, and financial constraints. This limitation indicates that the final generic criteria may be too broad for the finer scale issues in land use decision making.

To become more practical for the goal of socioecological sustainability, radical green political theorists must begin to reach beyond the broad concepts and theories that underpin its prescriptions for a sustainable society and focus attention on its orientation towards the finer details in real life, socioecological problem solving.

\section{BIBLIOGRAPHIE}

Dobson, A. (1990). Green Political Thought (Ist ed.), London, Unwin Hyman, 225 p.

Dobson, A. (2000). Green Political Thought (3rd ed.), London, New York, Routledge, 230 p.

Dobson, A. (2006). Green Political Thought (4th ed.), London, New York, Routledge, 240 p. 


\section{EUE • Radical Green Political Theory • a-82}

DRYZEK, J.S. (1987). Rational Ecology: Environment and Political Ecology, Oxford, New York, Basil Blackwell, 270 p.

DRYZEK, J.S. (1997). The Politics of the Earth: Environmental Discourses, Oxford, New York, Oxford University Press, $240 \mathrm{p}$.

ECKersLey, R. (2004). The Green State: Rethinking Democracy and Sovereignty, Cambridge, London, MIT Press, 33I p.

Gibson, R.B., S. Hassan, S. Holtz, J. TanseQ and G. WHITELAW. (2005). Sustainability assessment: Criteria and processes, London, Sterling, Earthscan, 254 p.

GoodIN, R.E. (1992). Green Political Theory, Cambridge, Oxford, UK, Polity Press, 250 p.

HeIlbroner, R. (1974). An Inquiry into the Human Prospect, New York, Harper and Row, 195 p.

PaehlKe, R. and D. Torgerson (eds.). (2005). Managing Leviathan: Environmental Politics and the Administrative State (2nd ed.), Toronto, Broadview Press, $35 \mathrm{I}$ p.

RYLE, M. (1988). Ecology and Socialism, London, Radius, I 22 p.

SALE, K. (1985). Dwellers in the Land: The Bioregional Vision, San Francisco, Sierra Club Books, 217 p.

SMITH, M.J. (1998). Ecologism: Towards Ecological Citizenship, Minneapolis, University of Minnesota Press, $107 \mathrm{p}$.

SMITH, G. (2003). Deliberative Democracy and the Environment: Environmental Politics, London, New York, Routledge, $176 \mathrm{p}$.

TORgerson, D. (1999). The Promise of Green Politics: Environmentalism and the Public Sphere, Durham, London, Duke University Press, $218 \mathrm{p}$. 